\title{
The Effects of Pension Information on Individuals' Economic Outcomes: A Survey
}

\author{
Stefania Basiglio *(D) and Noemi Oggero * \\ ESOMAS Department, University of Turin, 10124 Turin, Italy \\ * Correspondence: stefania.basiglio@unito.it (S.B.); noemi.oggero@unito.it (N.O.)
}

Received: 8 June 2020; Accepted: 17 August 2020; Published: 20 August 2020

\begin{abstract}
This paper provides an overview of a wide array of research investigating the effects of pension information on different individuals' economic outcomes. While many studies show that information provision increases knowledge, the evidence is mixed regarding its effects on behavior. Nevertheless, we draw some conclusions about the impact of pension information on three major economic outcomes, namely, retirement planning, choices pertaining individuals' labor supply, and savings decisions. We also highlight that the lack of knowledge prevalently hits the most vulnerable individuals in the society, such as women. As a consequence, not providing sufficient information could contribute to widening the gender gap in pensions.
\end{abstract}

Keywords: pension information; retirement; savings; gender gap

JEL Classification: D14; J26; J16

\section{Introduction}

In recent decades, many countries have shifted from defined benefit to defined contribution pension schemes, where pension information becomes crucial in order to make sound retirement decisions. As pointed out by (Mitchell 1988), a lack of pension knowledge "is troubling since workers may save or consume suboptimally, [ ... ] or retire earlier than they would have if equipped with better pension information." Such knowledge is related to information; thus, it also depends on the costs and benefits of gathering information (Gustman and Steinmeier 2005).

As public pensions constitute a substantial share of the whole retirement income for many workers, it also is important for governments to provide individuals with information about their public retirement benefits (Fornero et al. 2019). Public pension statements are certainly one way to do it. Looking at the United States, a 2001 Gallup survey found that respondents who reported receiving the Social Security statement were more knowledgeable about the program than those who did not. For instance, the study highlighted a significant increase in the number of respondents who knew the relationship between benefits and earnings, and that retirement age was increasing (Kritzer and Smith 2016). Additionally, workers who received the statement were much more likely to be able to provide an estimate of their future benefits (Mastrobuoni 2011).

While it has been found that pension information is effective in increasing retirement knowledge, the evidence is mixed regarding its impact on economic behaviors. Nevertheless, we carry out a comprehensive review of the effects of pension information, and we identify three broad areas of economic behavior that are affected by such information. We systematize the literature accordingly, and we organize the extant research findings into three major economic outcomes, namely, retirement decisions, choices pertaining individuals' labor supply, and life cycle trajectories. The remainder of the paper is as follows. In Section 2, we provide an overview on the structure of pensions systems in several OECD countries and point out how the pension communication in such countries works. 
We then focus on pension knowledge and retirement planning in Section 3, labor supply decisions in Section 4, and savings choices in Section 5. Section 6 elaborates on the pension gender gap, and Section 7 concludes the paper.

\section{Pension Systems and Pension Communication in OECD Countries}

Pension systems have generally been represented by three pillars. Exploiting the glossary of a briefing provided by the European Parliament, ${ }^{1}$ the "first pillar" (public) pensions are identified by "public statutory pensions administered by the state and usually financed from social insurance contributions and/or general tax revenues on a PAYG basis"; in some countries, statutory funded individual plans have been introduced alongside the first pillar (pillar Ibis). "Second pillar" (occupational) pensions are "private supplementary plans linked to an employment relationship". Finally, "third pillar" (personal) pensions are represented by "personal pensions, i.e., pre-funded private voluntary supplementary plans in which contributions are invested in an individual account managed by a pension fund or financial institution."

Occupational pension schemes are not present in all the OECD countries, and when present, can be voluntary or mandatory, while some countries have both (Eichhorst et al. 2011). Along this line, differences in the structure and various reforms of pension systems led to different pension arrangements in different countries. The vast majority of pension systems are public. However, occupational pension schemes and/or private mandatory and voluntary schemes have been introduced in several countries (European Commission 2009b).

Earnings-related, old-age, public pension schemes represent the main type of coverage in most countries, except, for example, Denmark, Greece, Ireland, and the Netherlands (European Commission 2009a). The great majority of European countries also provide a minimum guarantee pension which is usually means-tested to ensure a minimum adequacy for all retired people (Eichhorst et al. 2011). On the contrary, in some other countries such as Denmark, Ireland, the Netherlands, and the United Kingdom, the minimum guarantee pension is provided by a flat rate pension that pays the same amount to every retiree (European Commission 2009a, 2009b; Eichhorst et al. 2011).

Most pension schemes rely on a public pension (earnings-related) system. A fundamental indicator of the generosity of a pension scheme is the replacement rate, i.e., the percentage of a worker's preretirement monthly income that they monthly receive after retiring. Recent evidence shows that theoretical net replacement rates from mandatory schemes are on average $59 \%$, and the range is between almost 30\% in Lithuania and the United Kingdom and almost 90\% in countries such as Austria, Italy, and Portugal (OECD 2019). Hence, it becomes fundamental to investigate whether enough information is provided to people to understand if individuals are aware of how the pension system works in their own country.

Generally, countries with high replacement rates (approximately 70\%) did not make high investments in pension communication compared to countries with low replacement rates (around 50\% or lower) (Debets et al. 2018). Recently, some countries have improved the measures of transparency concerning, for example, costs and performance of pension funds. For instance, in the Netherlands, pensions funds have to report and provide detailed information on administration and investment costs. $^{2}$ Similarly, in Denmark, the government site made all direct and indirect administration and investment costs transparent for individuals, including past returns of individual accounts (OECD 2018).

The information contained in a pension statement can be classified into two categories: the first one provides a basic accounting information, i.e., all basic information about pension plans,

1 Briefing of the European Parliament available at: http://www.europarl.europa.eu/EPRS/EPRS-Briefing-568328-Prospects-foroccupational-pensions-EU-FINAL.pdf.

2 In 2011, the Dutch Authority for Financial Markets (AFM) published a report on pension fund costs emphasizing the influence of costs on retirement incomes, the potential for economies of scale, etc. (OECD 2018). 
while the second one consists of forward-looking information, i.e., something useful for individuals to understand potential returns, and relative risks, of the plans (Antolin and Harrison 2012). Indeed, pension projections represent an important tool which might help individuals to better understand what to expect after retirement. Differences in the pension systems could lead to differences in communication strategies. Hence, in this section, we want to provide some relevant examples of pension communication in several OECD countries. ${ }^{3}$ Before proceeding, it is important to highlight that the regulator or supervisor often establishes the assumption (or a range of assumptions) used for pension projections, but in some countries, there are no specific rules. Assumptions used in statements are more limited than those that can be used for website calculators, where the member has the facility to change one or more features in the calculation. The assumptions that countries make in their pension projections relatively to the website calculators and to the statements could vary from country to country (Antolin and Harrison 2012). Along this line, considering a broader perspective, assumptions could be different from the official ones for OECD or Ageing Working Group (AWG) standards. Indeed, as reported in the 2018 Ageing Report by the European Commission (European Commission 2017), each member state should fill in a pension projection sheet, following some guidelines, ${ }^{4}$ in which it is necessary to provide official projections using a common set of assumptions. ${ }^{5}$ By contrast, when considering the pension projections of individual entitlements, assumptions could diverge, and different institutions might be involved in the provision of forecasts of future pension benefits: these can be, for example, trustees, pension fund administrators, and pension fund managing companies (Stańko 2015). Next, we collect and present the different communication strategies stressing, when possible, the various assumptions made and the presence of official and/or additional calculators for several OECD countries. ${ }^{6}$

\subsection{Austria}

The pension system consists of a defined benefit public scheme with an income-tested top-up for low-income pensioners. It is based on the 45-65-80 rule: an $80 \%$ gross replacement rate for people with 45 years of social security contributions and retirement at 65 years old (Knell 2013; OECD 2019). This system is regulated by supervisory and regulatory authorities embodied by the Ministry of Social Affairs and Consumer Protection, the Ministry of Finance that regulates private pensions, and the Financial Market Authority that fixed the parameters for pension projections such as an assumed interest rate, a technical surplus, and an annual investment income. Collective bargaining agreements can require employers to enter a pension contract with a Pensionkasse. Pension fund members receive annual pension statements or other communications. Indeed, Pensionkassen (www.vbv.at/pensionskasse/) defines information requirements, mandates projections to be made and included in an annual pension benefit statement, and defines when projections are delivered. In 2013, there has been a pension information campaign in which the Pension Insurance Agency provided insured individuals born between 1958 and 1990 with information about their future pensions.

3 The choice of the countries that are going to follow lies in the fact that they share some common features in terms of pension systems, and it depends on the availability of information too.

4 Of course, when comparing different OECD countries, a common set of assumptions is needed: this ensures that the different economic conditions do not affect the outcomes of different pension models (European Commission 2018; OECD 2019). A complete list of all the variables used in outlining the OECD assumptions can be found in OECD Pension at a Glance 2019.

5 For example, the assumptions provided for OECD members in OECD Pension at a Glance 2019 are: "Real rate of return 3\%, real earnings growth $1.25 \%$, inflation $2 \%$, and real discount rate $2 \%$. All systems are modeled and indexed according to what is legislated. Transitional rules apply where relevant. DC conversion rate equals $90 \%$. Labour market entry occurs at age 22 in 2018".

6 The information provided in the next paragraphs is the result of our own elaboration of various data gathered through the consultancy of OECD (2019) and Stańko (2015), and various other sources taken directly from the platforms whose links are provided in the text itself. 


\subsection{Belgium}

The Belgian pension system consists of various pension schemes. There is an earnings-related public pension scheme, a means-tested safety net, and purely individual pension products. This system is regulated by the Financial Stability and Markets Authority. The law allows an organization created by different social security institutions, named Sigedis, to communicate with pension funds members. As for the private sector, pension communication is provided by the National Pensions Office. A career overview is sent annually, and a global career overview is sent every 5 years; at the age of 55, automatic estimations are sent and presume that the person will continue to work until the age of 65 . In the second pillar, the law sets the assumptions to use: e.g., retirement age equals 65 years old, contributions continue, vested reserves, and contributions are accumulated at an interest rate of $3.25 \%$ or $3.75 \%$. Currently, an integrated online platform (MyPension-www.mypension.be/nl) allows simulations of future career choices.

\subsection{Canada}

The pension system offers a universal flat rate benefit, which can be topped up with an income-tested benefit, earnings-related public schemes, and voluntary private pensions. It is supervised by the Canadian Association for Pension Supervisory Authorities. By law, workers can request a Statement of Contributions. For workers younger than 30, the statement only includes information on their contributions and pensionable earnings, omitting information on the retirement pension, disability benefit, survivor benefit, and lump-sum death benefit. By contrast, for those aged 30 or older, the statement includes information on their contributions, pensionable earnings, retirement pension (with the benefit receivable at age 65 listed before that receivable at age 60), disability benefit, survivor benefit, and the lump-sum benefit payable upon those individuals' death. In addition to the basic pension calculator provided by the Government of Canada, there are various online calculators provided by different commercial institutions that allow the calculation of pension projections.

\subsection{Czech Republic}

The Czech pension system consists of a public pension scheme and a voluntary funded private scheme which becomes mandatory once joined. The public pension scheme has a basic element and an earnings-related part calculated according to a progressive formula. There are no formal supervisory regulation authorities; indeed, conditions are set by law. Individual old-age pension amounts can be calculated using the pension calculators of the Ministry of Labor and Social Affairs or the pension calculator on the website of the Czech Social Security Administration.

\subsection{Denmark}

The public pension scheme consists of a basic pension and a means-tested pension supplement that is paid to the most financially disadvantaged pensioners. In addition, a mandatory occupation pension scheme is based on lump-sum contributions. Furthermore, compulsory occupational pension schemes cover about $90 \%$ of the employed labor force. This is regulated by the Danish Financial Supervisory Authority, the Ministry of Industry, Business and Financial Affairs, and the Ministry of Employment. No specific assumptions are given to calculate projections; indeed, through web calculators, individuals can choose a set of assumptions. However, it is important to notice that there is a web service known as PensionsInfo (www.pensionsinfo.dk/) that allows individuals to have complete and transparent information on pension rights and other relevant social security coverages.

\subsection{Estonia}

The pension system mandates an earnings-related public scheme with mandatory contributions to funded pensions. Two important regulatory and supervisory authorities need to be named: the Financial Supervision Agency that represents the supervisor of financial service providers, including 
Pension Management Companies, and Pensionikeskus (www.pensionikeskus.ee/) that is the institution in charge of opening pension accounts for the members of the mandatory pension funds. The calculator on the agency's website is generic and allows the pension fund members to fix few parameters such as the expected rates of return, contributions, and investment period.

\subsection{Finland}

The pension system is composed of a basic state pension and few statutory earnings-related schemes with almost the same rules for different groups. This is regulated by the Ministry of Social Affairs and Health, the Finnish Center for Pensions, and the Social Insurance Institution of Finland. The Finnish Center for Pensions (www.etk.fi/en/) is in charge of providing annual pension projections which offer three economic scenarios. The baseline, the optimistic, and the pessimistic economic scenarios differ from each other in terms of employment rate, growth of earnings, and return on pension assets. The data used to set the key assumptions come from administrative records and relate to demographic development, employment rates, retirement risk, growth in earnings, return on pension assets, and inflation. ${ }^{7}$

\subsection{France}

The pension system has two public mandatory tiers: a defined benefit public pension and occupational schemes, based on a points system. The defined benefit scheme includes a means-tested minimum contributory pension. In addition, there is a targeted minimum income for the elderly. This is supervised by the Ministry of Social Affairs and Labor and by the Prudential Supervisory and Resolution Authority. Mandatory occupational schemes are managed by private companies together with public institutions (Association générale des institutions de retraite complémentaire des cadres and Association pour le régime de retraite complémentaire des salaries). Pension fund members, using their own social security number, can control the career audit (on www.info-retraite.fr). Different online calculators provided by various commercial institutions allow the calculation of pension projections.

\subsection{Germany}

The public pension system has a single tier and is an earnings-related pay-as-you-go system. Similarly to France, the calculation of pensions is based on pension points. There is an additional voluntary private pension that can be provided by banks, insurance companies, or investment funds. The Federal Financial Supervisory Authority (BaFin-www.bafin.de) supervises pension funds as well as insurance companies. Concerning projections for the statutory pension system, pension information is always given on the basis of the prevailing law; two sample calculations are also given taking into account different income growth rates (1\% and $2 \%$ ). Starting from the age of 27 (given that at least five years of contribution payments have been completed), annual communications are sent; indeed, Deutsche Rentenversicherung sends out approximately 31 million pension communications by post each year.

\subsection{Hungary}

The pension system is a mandatory, uniform, defined benefit pay-as-you-go system with an earnings-related public pension combined with a minimum pension. There are no formal supervisory regulation authorities except for the Central Bank of Hungary. Moreover, there is no pension calculation neither in the reconciliation procedure nor in the case of a personal account. Indeed, the pension calculator is under construction.

7 A fully detailed list of these assumptions can be found at www.etk.fi/en/research-statistics-and-projections/projections/longterm-projections/assumptions-of-projections/. 


\subsection{Iceland}

The pension system provides a basic state pension, which is income-tested. There are also mandatory occupational pensions. The Ministry of Health and Social Security and the Ministry of Finance oversee the public pensions. As for pension projections, it is compulsory to present lifelong monthly annuity in pension benefit statements sent at least annually. Different online calculators provided by various commercial institutions allow the calculation of pension projections.

\subsection{Ireland}

The public pension system consists of a basic scheme paying a flat rate to all who meet the contribution conditions. Over half of employees are covered by voluntary occupational pension schemes. The Pensions Authority (www.pensionsauthority.ie/), Revenue (www.revenue.ie), and the Central Bank of Ireland are responsible for the regulation of the pension system. Indeed, it is mandatory to send annual projections on accumulated assets and predicted retirement income in a pension benefit statement. In addition to the official pension calculator provided by the Pensions Authority, ${ }^{8}$ there are various online calculators provided by different commercial institutions that allow the calculation of pension projections.

\subsection{Italy}

The pension system is structured as a compulsory statutory pension system integrated by voluntary private and fully funded pension plans at individual and collective levels; contributions are accrued at a rate of return related to real GDP growth. Once retired, the accumulated capital is converted into an annuity considering the average life expectancy at retirement. This system is regulated by the Pension Funds Supervision Commission. As for pension projections (assuming standardized macroeconomic scenarios), the supervisory authority annually mandates the presentation of annuities in pension benefit statements. Indeed, the Italian Social Security Institute (INPS) annually informs the workers of the evolution of their pensions. Starting from 2016, through the INPS website, private sector employees and the self-employed can control various information such as the day of retirement and the predicted replacement rate, and they can also simulate different scenarios dependent on different career patterns (Debets et al. 2018).

\subsection{Latvia}

The pension system combines an earnings-related public scheme, based on notional accounts, with mandatory contributions to pension funds. This system is regulated by the Finance and Capital Market Commission, the Ministry of Welfare, and the State Social Insurance Agency. Before 2011, the transparency in providing publicly available data for private pension funds was almost inexistent. Currently, it is expected that the government will focus on the further enhancement of the regulatory and monitoring framework of private pension arrangements, improvements of the participants' financial literacy, and monitoring fees and charges.

\subsection{Lithuania}

The pension system has a two-tier public scheme, with an earnings-related and a flat rate benefit. Voluntary contributions to a funded pension scheme are possible. This system is supervised by the Ministry of Social Security and Labor; in particular, the funded pension system is supervised by the Ministry of Social Security and Labor and the Bank of Lithuania. As for pension projections, authorities

\footnotetext{
8 https://www.pensionsauthority.ie/en/lifecycle/useful-resources/pension-calculator/.
} 
require the interpretation of results and the relative disclaimer. The official calculator ${ }^{9}$ allows few parameters to be set in order to calculate the projection.

\subsection{Luxembourg}

The public pension scheme has a flat rate part and an earnings-related part in addition to a minimum pension. This system is regulated by the Financial Sector Supervisory Commission (www.cssf.lu/), the Ministry of Social Security, the Commissariat aux Assurances, and the Inspection Générale de la Sécurité Sociale. Various online calculators provided by different commercial institutions allow the calculation of pension projections.

\subsection{Norway}

The pension system consists of an income pension and a guarantee pension for people with no or only a small income pension. The guarantee pension is income-tested against the income pension. In 2006, a mandatory occupational pension was introduced in the private sector as a supplement to the public pension. The private pension system is supervised by the Financial Supervisory Authority. Setting different parameters, pension fund members can calculate their own pension projections. ${ }^{10}$

\subsection{Poland}

The pension scheme is based on a system of notional accounts. People under 30 at the time of the reform (born in 1969 and after) must also participate in a funded scheme; people aged 30-50 (born between 1949 and 1968) could choose the funded option. However, the choice had to be made in 1999, and it was irrevocable, with the exception of those who could retire early. Since 2014, participation in the funded scheme is voluntary. This system is regulated by the Polish Financial Supervision Authority (www.knf.gov.pl/). In addition to the official pension calculator provided by the Social Insurance Institution, ${ }^{11}$ there are various online calculators provided by different commercial institutions that allow the calculation of pension projections. This enables members to estimate future pension and replacement rates from private pension funds and the social security pension, based on different assumptions about wages, the rate of return, and the labor market.

\subsection{Portugal}

Portugal has an earnings-related public pension scheme with a means-tested safety net. This system is supervised by the Portuguese Insurance and Pension Funds Supervisory Authority that regulates the occupational pension system.

\subsection{Slovak Republic}

The pension system is an earnings-related public scheme. There is a minimum amount of earnings for low-income workers. All retirees are eligible for social assistance benefits. In 2005, voluntary defined contribution plans were introduced. This system is regulated by the National Bank of Slovakia in charge of supervising pension funds and insurance companies. As for the calculation methods of pension projections, there are no specific rules. Additionally, authorities mandate individualized projections in a pension benefit statement that has to be sent annually to members of voluntary pension funds. Different online calculators provided by different commercial institutions allow the calculation of pension projections.

9 https://www.sodra.lt/lt/skaiciuokles/senatves_pensijos_amziaus_skaiciuokle.

10 https://tjenester.nav.no/pselv/simulering/forenkletsimulering.jsf?execution=e2s1.

11 Available online: https://www.zus.pl/swiadczenia/emerytury/kalkulatory-emerytalne/emerytura-na-nowych-zasadach/ kalkulator-emerytalny-prognozowana-emerytura. 


\subsection{Spain}

The public pension system consists of a single earnings-related benefit, with a means-tested minimum pension. This system is regulated by the Directorate General for Insurance and Pension Funds. As for the calculation of pension projections, the parameters are the same for all the categories of workers and fixed by the government regulations. Concerning the manner of the communication, it is paper-based, but the same information is available through the social security website. Different online calculators provided by different commercial institutions allow the calculation of pension projections.

\subsection{Sweden}

The national pension scheme consists of a pay-as-you-go notional accounts system, a mandatory funded defined contribution pension, and a defined benefit pension-income-tested top-up. Occupational pension plans with defined benefit and defined contribution elements have broad coverage. The institution responsible for the administration of public pensions is the Swedish Pensions Agency, while the financial regulator responsible for insurance companies and occupational pension funds is the Swedish Financial Supervisory Authority. Projections assume two wage growth scenarios: $0 \%$ and $2 \%$. The rate of return on the funded individual account is assumed to be $3.5 \%$ higher than the earnings growth. After the change from a defined benefit to a defined contribution pension system in 1999, the government introduced the Orange Envelope with the aim of improving information on pension contributions. The envelope, which is sent annually, includes an account statement, a report for the funded part, and a prevision for the future pension (Debets et al. 2018).

\subsection{The Netherlands}

The pension system can be categorized in three levels: the first one is a state income independent of the contribution history of the individual; the second one is a mandatory fully funded occupational pension plan; the third one is composed of individual voluntary pension savings. This system is regulated by the Central Bank of the Netherlands, the Ministry of Social Affairs and Employment, and the Financial Conduct Authority (www.afm.nl/). Funds are generally required to use an interest rate of $4 \%$, and it is free for members to choose their own mortality table. In 2007, a law on pension communication established that the pension industry had to provide a yearly Uniform Pension Overview (UPO); in addition to that, pension funds were obliged to send the UPO to the participants. Moreover, the pension industry was required to build up an online pension register in which people have complete information on first and second pillar pension rights (Debets et al. 2018). In 2015, a new Act on Pension Communication passed aiming to inform plan members about the expected amount and the relative risks of the pension plan. Different online calculators provided by different commercial institutions (such as banks) allow the calculation of pension projections.

\subsection{The United Kingdom}

Originally, the pension system could be categorized into three levels: the basic state retirement pension, the State Second Pension, and the Pensions Credit. No specific legislation on state pension was provided except for the supplementary pensions whose information is regulated by the Pension Schemes Act 1993. From 2016, the state pension system is a flat rate scheme. Along this line, for those who reached the retirement age before 2016, the public scheme has a flat rate basic pension and an earnings-related additional pension. They are then complemented by voluntary private pensions. Different authorities are involved in the regulation: the Department for Work and Pensions, responsible for welfare, pensions and child maintenance policy; the Pensions Regulator, which regulates UK work-based pension schemes; the Financial Conduct Authority, a regulator for a large part of financial services firms and financial markets in the UK and a prudential regulator for over 18,000 of those firms; the Prudential Regulatory Authority, responsible for the prudential regulation and supervision of banks, insurers, and major investment firms; Her Majesty's Revenue and Customs, the UK's tax, 
payments, and customs authority. Projections are based on a maximum assumed growth rate; in relation to the underlying assets, the rate should be reasonable. Forecasts of the state pension age and the amount of basic state pension are available online through the government website; in addition to that, free advices are offered through the webpage of state Pension Institutions and the Financial Conduct Authority (Debets et al. 2018).

\subsection{The United States}

The publicly provided pension benefit, known as social security, has a progressive benefit formula. There is also a means-tested top-up payment available for low-income retirees. Various regulatory and supervisory authorities are present; in particular: the Social Security Administration administers the public pension system; the Treasury Department supervises the collection of social security taxes through the Internal Revenue Service and supervises the payment of benefits and the management of social security funds; the Internal Revenue Service determines the tax-qualified status of plans; the Employee Benefits Security Administration enforces Employee Retirement Income Security Act's standards concerning reporting, disclosure, and fiduciary matters; the Pension Guaranty Corporation administers plan termination rules and an insolvency insurance program for private defined benefit plans. The Social Security Administration is required by law to send out the public pension statement. The Social Security Statement contains the worker's earnings history; the Social Security taxes paid by the worker; an estimate of potential retirement benefits at the early retirement age of 62, at the full retirement age, and at age 70; estimates of disability, survivor, and other auxiliary benefits. In 2000, a paragraph was added that encouraged the recipient to think about the advantages and disadvantages of retiring early (Kritzer and Smith 2016).

\section{Pension Knowledge and Retirement Planning}

Research has found that many people lack fundamental economic concepts and fail to plan for retirement even when they are close to it (Lusardi et al. 2018, 2020). This result has important consequences, since being able to develop retirement plans is crucial for retirement security and can explain why some people arrive close to retirement with very little wealth. Lusardi et al. (2017) showed that financial knowledge is key to wealth accumulation in a stochastic life cycle model, and they estimated that 30-40 percent of wealth inequality is accounted for by financial knowledge. Nevertheless, the role played by pension information is less clear.

An evaluation of a low-cost online financial and demographic literacy program was provided by Billari et al. (2017), who implemented it with the largest industrial pension fund in Italy. The program was found not only to increase participants' knowledge, but it also made individuals look for more information on financial markets and financial planning. Moreover, the authors showed that the positive effect lasted several months after the treatment.

A few studies directly evaluated the effect of providing public retirement benefits information through public pension statements. In the United Sates, where the Social Security Administration fielded many surveys to evaluate its outreach effort, a considerable percentage of respondents reported using the statement for retirement planning, even though they did not believe they would receive Social Security benefits at the time they retire (Kritzer and Smith 2016). Even though there is widespread awareness of the unsustainability of pension systems, people seem to ignore or underestimate the cost of a public pay-as-you-go system (Boeri et al. 2002). These results might also be a consequence of low levels of financial literacy and understanding of retirement schemes (Oggero 2019). Allen et al. (2016), examining 85 preretirement planning seminars conducted by five companies in 2008 and 2009, showed that the exposure to them led to a considerable improvement in the knowledge of retirement programs and in the making of retirement choices, in addition to a reduction in transaction costs of managing pension plans.

In Sweden, where a notional defined contribution scheme provides a large share of retirement income, a lot of financial information-including forecasts of the expected future value of pension 
benefits-has been distributed through the so-called Orange Envelope to everybody eligible for a pension. The widespread dissemination of information is likely to have raised basic financial knowledge and have lowered the barriers to planning for retirement (Almenberg and Säve-Söderbergh 2011). However, fewer than half the recipients reported having a good understanding of the pension system (Sundén 2009). In Canada, public statement recipients said they had a better understanding of their pension plan and were more likely to plan for their retirement (Kritzer and Smith 2016). As a spillover effect, knowledge on the pension system and the personal pension situation decreases individuals' concerns about retirement, especially for women (Spruit 2018).

In line with these studies, Debets et al. (2018) exploited the introduction of an annual pension overview for all Dutch employees to estimate the effect of providing information on pension knowledge and active planning by identifying with this expression individuals that are not procrastinating in making retirement decisions. The research suggested that providing an annual pension statement might have a positive impact on pension knowledge, which in turn has a positive causal effect on active pension decision making, meaning that people will adjust their behavior if pensions are cut (or will not adjust it if they can easily make ends meet).

The evidence presented so far clearly shows that pension information has a positive impact on workers' knowledge about their benefits and their self-declared retirement planning, but whether workers actually change their retirement behavior after receiving pension information is more controversial. In particular, Mastrobuoni (2011) focused on the introduction of the annual Social Security Statement in 1995, and using the Health and Retirement Study data, he found that workers did not update their expectations after receiving the public statement, nor did Social Security claiming patterns change. The study concluded that "either workers were already behaving optimally or the additional information provided by the statement isn't sufficient to improve uninformed workers' retirement choices" (Mastrobuoni 2011).

\section{Labor Supply Decisions}

From a theoretical point of view, little attention has been devoted to overlapping generations models where agents choose the time to devote to labor both when young and old (Gori and Sodini 2011). A notable exception is the model by Aísa et al. (2012), which showed that the individuals who decide to stay in the labor market at older ages are those with the highest levels of productivity. Additionally, Bloom et al. (2007) found that in countries characterized by strong incentives to retire, the retirement age may effectively be fixed, so that longer life spans lead to longer periods of retirement. However, no theoretical model has specifically investigated the impact of pension information on individuals' economic outcomes.

The shift to defined contribution pension plans that link the benefit to the contributions paid is altering the incentives to work longer, since postponing retirement leads to higher pension levels. However, these incentives only work if workers are provided with information about the pension system (Chlon-Dominczak 2009). In fact, using self-reported, employer-reported, and administrative data, Chan and Stevens (2008) showed that only those who correctly perceive the incentive to delay retirement are responsive to pension incentives, while misinformed individuals respond to their perceived, but incorrect, pension information. In particular, among individuals who can increase their pension wealth by postponing retirement, those that are aware of this are less likely to retire. This is partly in contrast with the successive research finding that workers do not become more sensitive to Social Security incentives after receiving information through the public statement. A possible explanation is that additional information is valuable only for workers who do not face health problems or liquidity constraints: indeed, wealthier and healthier individuals are more likely to get informed (Mastrobuoni 2011).

Since many countries have started providing workers with information about their public retirement benefits through public pension statements, the economic research investigating the effects of pension information is exploiting a related event-study strategy. In this regard, Dolls et al. (2018) 
used an event study coupled with administrative tax returns and survey data to investigate the consequences of the first receipt of a public statement. In particular, they studied the effect of the German pension administration decision to send out annual letters providing information about both the pension system and individual expected public pension benefits. Focusing on labor supply decisions, the authors found that receiving the letter caused an increase in gross labor earnings, which is the most direct way to increase public pension benefits through higher contributions.

In order to measure the impact of the information provision on labor supply, Liebman and Luttmer (2015) designed a field experiment in which a treatment group of older workers was given information about Social Security provisions trough a brochure and a short online tutorial. A follow-up survey conducted the subsequent year revealed that the intervention raised the fraction of individuals remaining in the labor force and increased the perceived return to working longer, especially among women, by changing knowledge of incentives. Along this line, women exposed to a financial education seminar are found to be more likely to change retirement objectives willing to increase contributions (Clark et al. 2006).

Finally, exploiting surveys conducted before and after financial education programs, Allen et al. (2016) found that individuals, in addition to having their own knowledge in retirement programs and plans increased, were more willing to revise the planned retirement age and the age for demanding Social Security benefits.

\section{Savings Trajectories}

While the research on the effects of pension information provision on labor supply is scant, more has been performed to study its effects on savings and wealth accumulation. Research cited in the previous section also provides causal evidence of the positive effect of information letters on private retirement savings. Specifically, Dolls et al. (2018) showed that the receipt of public statements increased private retirement savings, which did not crowd-out other forms of savings. The information effect on both savings and labor supply is explained by the fact that individuals tend to overestimate their pension benefits, implying that the letter represents a negative shock.

Using a randomized field experiment and administrative data on employees at the University of Minnesota, Goda et al. (2014) found that a low-cost provision of retirement planning materials and retirement income projections increased workers' contributions. However, differently than Dolls et al. (2018), they could not rule out a crowding-out of other forms of savings. This experiment also showed the importance of the assumptions used to generate the projections: higher assumed retirement age and contributions led to a larger increase in contributions. In line with this research, Smyrnis et al. (2019) investigated the relevance of presenting retirement wealth in different ways to plan-participants. More specifically, using an online experimental survey, they showed that just inviting respondents to consider their retirement wealth increased voluntary saving, and the provision of lump-sum together with income stream projections had the largest impact on savings.

Following the line of randomized experiments, Duflo and Saez (2003) conducted a field experiment in which a random sample of university employees were provided a monetary reward to attend seminars on retirement benefits. They found that enrollment in the retirement plan increased significantly in university departments where some workers were treated with respect compared to departments where nobody was treated with respect, also highlighting the role played by social interactions. However, social interactions could also have the opposite effect when information about the high savings rates of peers discourages individuals, leading low-saving people to decrease their savings (Beshears et al. 2015).

Offering financial education seminars in the workplace assumes a crucial role in shaping saving behavior (both in general and for retirement) and participation in retirement plans. Indeed, Bernheim and Garrett (2003) found that when an employer offers some financial education programs, retirement accumulation and rates of participation in retirement plans are significantly higher both at the individual and household level. 
Furthermore, as pointed out also in previously cited works, financial literacy could represent an important driver for participation in retirement plans. Brown and Graf (2013), using survey data representative of the Swiss population, showed that high levels of financial literacy are strongly correlated with voluntary retirement savings. Indeed, Fornero and Monticone (2011) found that financial literacy increases the chances of investing in a private pension plan. Going beyond changes in saving behaviors, the last aspect that needs attention is related to the capability of modifying investment choices in retirement accounts. Indeed, Clark et al. (2006) claimed that, after participating in financial education seminars, individuals are more likely to change investment allocations and start new tax deferred saving accounts. Along this line, Boyer et al. (2019) pointed out the importance of filling the knowledge gap of tax-sheltered retirement instruments in Canada. In a randomized experiment, the authors proposed a survey through which they showed a significant improvement both in the knowledge about tax-favored saving vehicles and in the quality of the decisions made.

\section{The Pension Gender Gap}

The research reviewed so far does not focus on the gender dimension, with only few studies touching upon it. However, a natural and straightforward conclusion drawn from the different aspects considered here is that the lack of information and knowledge could mostly affect more vulnerable individuals in the society, such as women (Angelici et al. 2020). In fact, pension benefits are first of all a consequence of the position that individuals hold in the labor market, and occupations depend on various features such as stability, labor market segregation, and wage gaps (Frericks et al. 2009).

Disadvantageous conditions in the labor market cause lower pensions for women even when working hours or occupational positions are the same as those of men. Indeed, as pointed out by Bettio et al. (2013) and Tinios et al. (2015), people often associate the concept of economic independence with the gender pay gap. Going one step further, the authors examine the pension gender gap, defined as the difference between the gross pensions of men and women over age 65 .

The different spread out of women's emancipation in the labor market is one of the factors responsible for differences in pension wealth accumulation. Older cohorts are indeed more influenced by past gender inequality. As reported in Lis and Bonthuis (2019), "pensions of women are substantially lower than those of men, by 27 percent on average across the EU but by more than 40 percent in a few European countries. This average gap is higher than the one for hourly earnings at 14 percent".

From a US perspective, Even and Macpherson (2004) analyzed the gender gap in Social Security and pension income between 1980 and 2000, and they highlighted the fact that, despite increases in female labor force participation and earnings, women tend to accumulate less pension wealth compared to men. Similar conclusions were drawn by Gough (2001), who aimed to understand and examine the different drivers of women's labor earnings that contribute to the earnings in retirement. Using data from the Labor Force Survey, the author found that part-time working, types of occupation, and employment represent the main reasons why women's incomes are lower than men's, and, as a consequence, after retirement, women appear to have reduced entitlement to benefits from pension schemes (Gough 2001). Therefore, focusing on the gender gap in pensions is fundamental to understand the well-functioning of a pension system; it is indeed an indicator of gender equality at older ages and might be useful in pointing out labor market inequalities (Lis and Bonthuis 2019).

Enhancing programs aimed at the improvement of financial literacy and pension knowledge in particular could represent a first step toward the awareness of the gender gap. Along this line, a recent OECD report points out that in many countries, the levels of financial literacy are very low, especially for women. Cross-comparable data from 30 countries and economies show that "overall levels of financial literacy are relatively low, with an average score of 13.2 out of a maximum of 21 " (OECD 2016). It continues underlining that "on average, only $56 \%$ of adults achieve the minimum target score on financial knowledge, with significant differences by gender, as $61 \%$ of men achieve the minimum target score, compared to $51 \%$ of women" (OECD 2018). 


\section{Discussion}

The pension wealth accumulation depends on different factors; among these, information as well as the ability of using it sagely. In fact, given all the changes that occurred during recent decades, pension information assumed a crucial role in order to make sound retirement and financial decisions.

This paper aimed to shed light on the role of pension information on individuals' economic outcomes. Examining different studies, we elicited some conclusions about the effects of pension information on three broad areas of economic behavior into which we systematized the literature: retirement planning, labor supply, and savings decisions. Specifically, the provision of pension information not only increases workers' knowledge about their benefits, but it also fosters individuals' retirement planning and decision making. Looking at individuals' labor supply, our review of the literature showed that only correctly informed workers are responsive to the incentives to work longer. Finally, information letters and other educational interventions such as seminars are found to increase both enrollment in retirement plans and the amount of contributions.

When analyzing how people's decision making might change through public policies, workplace initiatives, and other types of intervention, it is impossible not to direct our attention toward more vulnerable individuals, such as women. Pensions systems, being in some way a natural reflection of other policy choices (labor market, schooling, etc.), might enhance or lessen social imbalances (Bettio et al. 2013). The gender pension gap is indeed also a consequence of women's low and discontinuous involvement in the labor market. Women, considering different life patterns and societies where they live, generally face many difficulties in the labor market: this is why pension entitlements could be a consequence of structural disadvantages (Frericks et al. 2009).

Policy makers should take into account the findings summarized here when designing public policies, as transparent information about retirement systems enhances individuals' retirement planning and decision making. Additionally, future pension policies should devote more attention to the drivers of the gender gap in pensions to reduce gender inequality at older ages. The lack of appropriate policies aimed at reducing not only wages but also the pension gender gap could indeed represent a threat for the financial security of the elderly. Along this line, as suggested by Barr (1916), policy makers, when designing pension reforms, should take into account how changes imposed by new regulations may affect both men and women, since women are often involved in activities that exclude them from the labor market, such as taking care of children and parents.

Finally, we mention that in the United States, individuals faced difficulties in understanding complicated aspects of retirement planning (Samek et al. 2019). ${ }^{12}$ Hence, after having designed an appropriate policy, it becomes fundamental to build an adequate channel of information in order to ensure that individuals correctly understand it, and the way of communicating matters too.

Funding: This research was cofunded by the Rights, Equality and Citizenship Programme of the European Union (Grant Agreement number: 820763).

Acknowledgments: The authors would like to thank three anonymous referees and the research team of the project "CLEAR-Closing the gender pension gap by increasing women's awareness": Marta Angelici, Daniela Del Boca, Paola Profeta, Mariacristina Rossi, and Claudia Villosio.

Conflicts of Interest: The authors declare no conflict of interest. The funders had no role in the design of the study; in the collection, analyses, or interpretation of data; in the writing of the manuscript, or in the decision to publish the results.

12 On the importance of communication, Samek et al. (2019) conducted a randomized experiment in which, after having created some vignettes about the consequences of different annuitization and decision-making in retirement, they showed that people exposed to vignettes, compared to those of the control group, were more able to give better advice. 


\section{References}

Aísa, Rosa, Fernando Pueyo, and Marcos Sanso. 2012. Life expectancy and labor supply of the elderly. Journal of Population Economics 25: 545-68. [CrossRef]

Allen, Steven G., Robert L. Clark, Jennifer Maki, and Melinda Sandler Morrill. 2016. Golden years or financial fears? How plans change after retirement seminars. Journal of Retirement 3: 96-115. [CrossRef]

Almenberg, Johan, and Jenny Säve-Söderbergh. 2011. Financial Literacy and Retirement Planning in Sweden. Journal of Pension Economics and Finance 10: 585-98. [CrossRef]

Angelici, Marta, Daniela Del Boca, Noemi Oggero, Paola Profeta, Mariacristina Rossi, and Claudia Villosio. 2020. Pension Information and Women's Awareness. IZA Discussion Paper No. 13573. Bonn: IZA.

Antolin, Pablo, and Debbie Harrison. 2012. Annual DC Pension Statements and the Communications Challenge. In OECD Working Papers on Finance, Insurance and Private Pensions No. 19. Paris: OECD Publishing.

Barr, Nicholas. 1916. Gender and Family: Conceptual Overview. Social Protection and Jobs Discussion Paper. No. 1916. Washington: World Bank.

Bernheim, Douglas B., and Daniel M. Garrett. 2003. The effects of financial education in the workplace: Evidence from a survey of households. Journal of Public Economics 87: 1487-519. [CrossRef]

Beshears, John, James J. Choi, David Laibson, Brigitte C. Madrian, and Katherine L. Milkman. 2015. The effect of providing peer information on retirement savings decisions. The Journal of Finance 70: 1161-201. [CrossRef]

Bettio, Francesca, Platon Tinios, and Gianni Betti. 2013. The Gender Gap in Pensions in the EU. Rome: European Institute for Gender Equality.

Billari, Francesco C., Carlo A. Favero, and Francesco Saita. 2017. Nudging Financial and Demographic Literacy: Experimental Evidence from an Italian Trade Union Pension Fund. BAFFI CAREFIN Working Paper No. 1767. Milano, Italy: Centre for Applied Research on International Markets Banking Finance and Regulation, Università Bocconi.

Bloom, David E., David Canning, Richard K. Mansfield, and Michael Moore. 2007. Demographic change, social security systems, and savings. Journal of Monetary Economics 54: 92-114. [CrossRef]

Boeri, Tito, Axel Börsch-Supan, and Guido Tabellini. 2002. Pension reforms and the opinions of European citizens. American Economic Review Papers and Proceedings 92: 396-401. [CrossRef]

Boyer, Martin M., Philippe D'Astous, and Pierre-Carl Michaud. 2019. Tax-Sheltered Retirement Accounts: Can Financial Education Improve Decisions? Working Paper No. 26128. Cambridge: National Bureau of Economic Research.

Brown, Martin, and Roman Graf. 2013. Financial literacy and retirement planning in Switzerland. Numeracy 6: 6. [CrossRef]

Chan, Sewin, and Ann Huff Stevens. 2008. What you don't know can't help you: Pension knowledge and retirement decision-making. The Review of Economics and Statistics 90: 253-66. [CrossRef]

Chlon-Dominczak, Agnieszka. 2009. Retirement Behaviour in Poland and the Potential Impact of Pension System Changes. ENEPRI Research Report No. 61. Brussels: ENEPRI.

Clark, Robert L., Madeleine B. Ambrosio, Ann A. D'McDermed, and Kshama Sawant. 2006. Retirement plans and saving decisions: The role of information and education. Journal of Pension Economics E Finance 5: 45-67.

Debets, Steven, Henriette Prast, Maria Cristina Rossi, and Arthur van Soest. 2018. Pension Communication in the Netherlands and Other Countries. CentER Discussion Paper Series No. 2018-047. Tilburg: CentER.

Dolls, Mathias, Philipp Doerrenberg, Andreas Peichl, and Holger Stichnoth. 2018. Do retirement savings increase in response to information about retirement and expected pensions? Journal of Public Economics 158: 168-79. [CrossRef]

Duflo, Esther, and Emmanuel Saez. 2003. The role of information and social interactions in retirement plan decisions: Evidence from a randomized experiment. Quarterly Journal of Economics 118: 815-42. [CrossRef]

Eichhorst, Werner, Maarten Gerard, Michael J. Kendzia, Christine Mayrhuber, Conny Nielsen, Gerhard Rünstler, and Thomas Url. 2011. Pension Systems in the EU-Contingent Liabilities and Assets in the Public and Private Sector. IZA Research Report No. 42. Bonn: IZA.

European Commission. 2009a. Directorate-General for Economic and Financial Affairs. In The 2009 Ageing Report, Economic and budgetary projections for the EU-27 Member States (2008-2060). European Economy No. 2/2009. Brussels: European Commission. 
European Commission. 2009b. Directorate-General for Economic and Financial Affairs. In Pension Schemes and Pension Projections in the EU-27 Member States-2008-2060. European Economy No. 56. Brussels: Office for Official Publications of the European Communities.

European Commission. 2017. The 2018 Ageing Report. Underlying Assumptions E Projection Methodologies. Institutional Paper 065. Brussels: European Commission.

European Commission. 2018. Directorate-General for Employment, Social Affairs and Inclusion. In The 2018 Pension Adequacy Report: Current and future income adequacy in old age in the EU. Brussels: European Commission, vol. 1.

Even, William E., and David A. Macpherson. 2004. When will the gender gap in retirement income narrow? Southern Economic Journal 71: 182-200. [CrossRef]

Fornero, Elsa, and Chiara Monticone. 2011. Financial literacy and pension plan participation in Italy. Journal of Pension Economics \& Finance 10: 547-64.

Fornero, Elsa, Noemi Oggero, and Riccardo Puglisi. 2019. Information and financial literacy for socially sustainable NDC pension schemes. In Progress and Challenges of Nonfinancial Defined Pension Schemes: Volume 2. Addressing Gender, Administration, and Communication. Washington: World Bank Publications, pp. 187-216.

Frericks, Patricia, Trudie Knijn, and Robert Maier. 2009. Pension reforms, working patterns and gender pension gaps in Europe. Gender, Work \& Organization 16: 710-30.

Goda, Gopi Shah, Colleen Flaherty Manchester, and Aaron J. Sojourner. 2014. What will my account really be worth? Experimental evidence on how retirement income projections affect saving. Journal of Public Economics 119: 80-92. [CrossRef]

Gori, Luca, and Mauro Sodini. 2011. Nonlinear Dynamics in an OLG Growth Model with Young and Old Age Labour Supply: The Role of Public Health Expenditure. Computational Economics 38: 261-75. [CrossRef]

Gough, Orla. 2001. The impact of the gender pay gap on post-retirement earnings. Critical Social Policy 21: 311-34. [CrossRef]

Gustman, Alan L., and Thomas L. Steinmeier. 2005. Imperfect knowledge of Social Security and pensions. Industrial Relations 44: 373-97. [CrossRef]

Knell, Markus. 2013. The Austrian system of individual pension accounts-An unfinished symphony. Monetary Policy \& the Economy 13: 47-62.

Kritzer, Barbara E., and Barbara A. Smith. 2016. Public pension statements in selected countries: A comparison. Social Security Bulletin 76: 27-56.

Liebman, Jeffrey B., and Erzo F. P. Luttmer. 2015. Would people behave differently if they better understood social security? Evidence from a field experiment. American Economic Journal: Economic Policy 7: 275-99. [CrossRef]

Lis, Maciej, and Boele Bonthuis. 2019. Drivers of the gender gap in pensions: Evidence from EU-SILC and the OECD pension model. In Social Protection and Jobs Discussion Paper. No. 1917. Washington: World Bank.

Lusardi, Annamaria, Pierre-Carl Michaud, and Olivia S. Mitchell. 2017. Optimal financial knowledge and wealth inequality. Journal of Political Economy 125: 431-77. [CrossRef] [PubMed]

Lusardi, Annamaria, Olivia S. Mitchell, and Noemi Oggero. 2018. The changing face of debt and financial fragility at older ages. American Economic Association Papers and Proceedings 108: 407-11. [CrossRef]

Lusardi, Annamaria, Olivia S. Mitchell, and Noemi Oggero. 2020. Debt and Financial Vulnerability on the Verge of Retirement. Journal of Money, Credit and Banking 52: 1005-34. [CrossRef]

Mastrobuoni, Giovanni. 2011. The role of information for retirement behavior: Evidence based on the stepwise introduction of the Social Security Statement. Journal of Public Economics 95: 913-25. [CrossRef]

Mitchell, Olivia S. 1988. Worker knowledge of pension provisions. Journal of Labor Economics 6: 21-39. [CrossRef] OECD. 2016. OECD/INFE International Survey of Adult Financial Literacy Competencies. Paris: OECD Publishing.

OECD. 2018. OECD Pensions Outlook 2018, OECD Pensions Outlook. Paris: OECD Publishing. [CrossRef]

OECD. 2019. Pensions at a Glance 2019: OECD and G20 Indicators. Paris: OECD Publishing. [CrossRef]

Oggero, Noemi. 2019. Retirement Expectations in the Aftermath of a Pension Reform. Working Paper No. 197/19. Turin: Center for Research on Pensions and welfare Policies.

Samek, Anya, Arie Kapteyn, and Andre Gray. 2019. Using Vignettes to Improve Understanding of Social Security and Annuities. Working Paper No. 26176. Cambridge: National Bureau of Economic Research.

Smyrnis, George, Hazel Bateman, Isabella Dobrescu, Ben Newell, and Susan Thorp. 2019. Motivated Saving: The impact of Projections on Retirement Saving Intentions. Netspar DP 01/2019-012. Tilburg: Netspar. 
Spruit, Jordi. 2018. Does Pension Awareness Reduce Pension Concerns? Causal Evidence from The Netherlands. Netspar Academic Series MSc 06/2018-04. Tilburg: Netspar.

Stańko, Dariusz. 2015. Design and Supervision of Pension Projections in 26 Jurisdictions (No. 34). IOPS Working Papers on Effective Pensions Supervision. Paris: IOPS.

Sundén, Annika. 2009. Learning from the experience of Sweden: The role of information and education in pension reform. In Overcoming the Saving Slump. Chicago: University of Chicago Press, pp. 324-44.

Tinios, Platon, Francesca Bettio, Gianni Betti, and Thomas Georgiadis. 2015. Men, Women and Pensions. Luxembourg: Publications Office of the European Union.

(C) 2020 by the authors. Licensee MDPI, Basel, Switzerland. This article is an open access article distributed under the terms and conditions of the Creative Commons Attribution (CC BY) license (http://creativecommons.org/licenses/by/4.0/). 